\title{
Reforming Islamic Finance for Achieving Sustainable Development Goals
}

\author{
Tariqullah Khan \\ Professor of Islamic Finance, College of Islamic Studies, \\ Hamad Bin Khalifa University, Qatar
}

\begin{abstract}
The paradigm of Islamic economics and finance is guided by the motivation of comprehensive human development (CHD) and its preservation as manifested in the objectives of Sharī'ah (maqāssid al-Sharī ah). However, the real world free-market economies are driven by the linear economy paradigm under the influence of Hotelling's 1931 famous work concerning the economics of exploiting natural resources, in which, the ecological environment is not recognized as a resource. The global financial architecture is designed to protect and preserve the linear economic paradigm. In practice, Islamic finance has also remained a halāl sub-set of this system. The resultant social, environmental, and governance imbalances have recently led to different initiatives sponsored by the UN including the Sustainable Development Goals (SDGs). Like the maqāșid, the SDGs also aim at achieving and preserving human development. In practice, for the first time, a real paradigm shift from the linear to the ecological/circular economy is noticeably taking place, also inducing the transformation of the financial architecture. In this paper, in a broader perspective, we use the CHD and SDGs interchangeably, and discuss a number of paradigmatic and regulatory reforms that will be required to enhance the actual effectiveness of Islamic finance in achieving the ideals of CHD, and the SDGs at large. The paper in fact outlines a wider scope of the potential reform initiatives.
\end{abstract}

Keywords: Maqāșid al-Sharīah, SDGs and Islamic finance, SDGs and design of financial contracts, Reforming Islamic finance, Regulating Islamic finance, Circular economy and Islamic finance, Reforming Sharīah governance; Reporting SDGs, ESGs and Islamic finance.

JEL Classification: Q01, Q56

KAUJIE Classification: B5, H51 


\section{Introduction}

Transformation of societies and economies, and development of the relevant institutional architecture and infrastructure, is a continuous process. What is the Islamic vison of development that can be used as a criterion for benchmarking the desirable transformation? This question became pertinent during 2006 when the Islamic Development Bank (IDB) went through an internal reform and a new 'Vision 1440H' for comprehensive human development (CHD) was formulated and adopted. The intellectual discourse concerning the reform, in fact, triggered a motivation for more detailed and formal academic works on the CHD, the first among these being Chapra's "The Islamic Vision of Development in the Light of Maqāșid al-Sharī'ah" (Chapra, 2008). Since then, a sizeable literature on the maqāssid and its contemporary applications has emerged. Tag el-Din (2013), is a good example of attempting to relate the maqāssid framework for achieving balanced socio-economic development in the free market economy.

The CHD is achieved by simultaneously upholding and preserving the human necessity for: (a) religious faith, (b) life with dignity, (c) progeny and future generations, (d) responsible mind and intellect, and (e) wealth and graceful sustenance. As elaborated in the above cited works of Chapra and Tag el-Din, the maqāssid framework was developed by scholars like al-Ghazali, Ibn Taimiyyah, Ibn al-Qayyim and al-Shatibi during the $12^{\text {th }}$ and $14^{\text {th }}$ centuries. The framework has remained as the architectural foundations of an ideal Islamic economics and finance paradigm. As such, the maqāssid represent the local aspirations of the society.

Economic development parse has always remained in the agenda of national governments with different ideological motivations, manifestations, achievements, and frustrations. In recent years, one measure of the progress of countries was the UN millennium development goals (MDGs). The MDGs era (20002015) ended with mixed results. Progress was made in several areas but MDG-1, concerning elimination of absolute poverty, remained largely unaccomplished. Most of this failure still remains in member countries of the IDB as documented in the IDB MDG target study (Bello \& Suleman, 2011). Since 2016, the UN has embarked upon a new development program termed as the sustainable development goals - SDGs (see appendix section A for the complete list). In IDB member countries, SDG-1 still remains to be MDG-1 in scope and challenge. In this specific SDG, financial inclusion is a priority area and Islamic finance promotes access to financial services by removing the faith-barrier to conventional finance.

Apart from SDG-1, there are several other similarities between the SDGs and MDGs. However, the SDGs are, in fact, a paradigm shift from MDGs. The MDGs followed the conventional capitalistic linear economy paradigm - its core being that the environment is not a resource and wealth creation is the necessary and sufficient condition to cater to the interest of the economy and future generations. The SDGs, on the other hand, are augmented by the United Nations (UN) Global Compact Principles (GCPs), UN Principles of Responsible Investments (PRIs), and the Global Reporting Initiative (GRI \& UN Global Compact, 2017). The goals of the SDGs and the GCPs and PRIs are given in the appendix. In addition to the UN, other institutions such as those of the European Union are actively engaged in a paradigm shift from linear to an ecological and circular economy (see, for example, European Commission, 2017).

In the existing linear paradigm, wealth creation could inflict further damage to the ecological environment, and hence could be disastrous in its consequences for the future security of humankind and other species. With this background, a new global financial architecture motivated by the SDGs implementation requirements is emerging, parallel to Basel III. In addition, the pressure on the existing global financial architecture is also increasing due to the emergence of the distributed ledger technology (DLT) and potential financial disintermediation.

Another important area of shift in paradigm is in the role of faith (local aspirations) as a positive motivating force for achieving SDGs as compared to the MDGs regime, which took it for granted that faith is a barrier to accessing health, educational, and financial services. Religious philanthropies and faith-based finance can enhance resources for the SDGs in the 
frame-work of a blended approach along with public sector resources and private investments. Unlike the MDGs, the SDGs give importance to local realities, values, and institutions. More importantly, faithdriven policies like Islamic finance can be consistent with local aspirations and could be readily owned by the relevant population segments. This brings the SDGs closer to the maqāssid al-Sharī' ah driven CHD.

The paradigm-shift in the SDGs opens up opportunities for Islamic finance that were not available under the MDGs. Therefore, there is the expectation that Islamic finance can play an important and wider role in achieving the SDGs. This potential role of Islamic finance can be enhanced by paradigmatic and regulatory reform and support as well as surveillance. In this regard, we identify the following broader areas and these areas could also be themes for future research:

(a) Facilitating a shift from the linear economy paradigm to a circular/ecological economy paradigm;

(b) Transformation of the global financial architecture;

(c) Developing synchrony between local aspirations (maqāṣid al-Sharī'ah), national goals, and the SDGs;

(d) Reforming Sharī'ah governance by taking into account the synchrony between the local aspirations, national goals, and the SDGs, and by integrating the Islamic institutions of compassion in financial sector reforms;

(e) Strengthening the Islamic financial architecture by removing structural risks in the design of financial products;

(f) Incentivizing waste control and management and promoting SMEs in ecological/circular economy; and

(g) Encouraging integrated reporting on SDGs.

\section{Shift the Paradigm}

One of the prime objectives of the Shari ah is the protection and preservation of the rights of future generations and the enhancement of opportunities and security for them. In this context, intergenerational equity is an important debate and environmental balance has significant implications for future welfare and security. With a similar perspective, the conservationist movement for protecting natural resources and the environment was initiated by the early 1900s. In a seminal article, Hotelling (1931) offers an economic refutation of the conservationist arguments. Briefly, he argues that in the interestbased financial system, the interest mechanism will dictate through market forces whether it is more profitable to conserve the environment or to transform the environment into financial resources and transfer these to financial institutions and markets and earn financial returns. Hotelling argued for the transformation instead of conservation of natural and environmental resources. Costanza et al. (1997) explain that:

According to Hotelling's model, even when market prices fully reflect the value of a species, it will be efficient to exploit a species to extinction or totally degrade an ecosystem if the value of the species or the ecosystem over time is not increasing at least as fast as money deposited in an interest-bearing bank account. (p. 54)

This argument was so convincing that it has dominated economic thought and policies ever since its publication in 1931. It is obvious that, in the model, the environment as such cannot be considered as a resource. The more it is extracted, the man-made capital/wealth can be created, the more is consumed and wasted. Given an effective demand through the credit mechanism, the more resources could be extracted. In this manner, the economy becomes a linear system of extracting, using, wasting, and extracting more. The interest-based financial system essentially becomes an engine for driving such a linear economy. 
Figure (1) Global Economy 2017 US\$ trillions

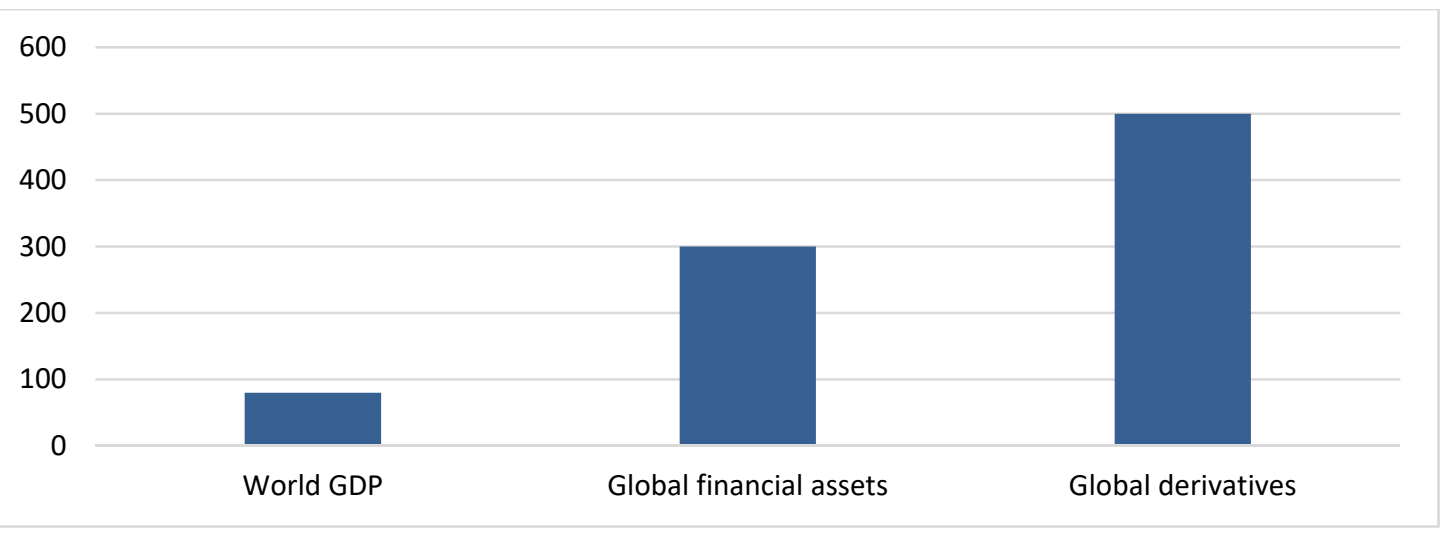

Sources: Data about the size of derivatives is from BIS, data about financial assets is from McKinsey and company, data about world GDP is from World Bank sources.

Figure 1 presents a picture of the global (linear) economy for 2017: World GDP about $\$ 80$ trillion, world financial assets about $\$ 300$ trillion and world derivatives about $\$ 500$ trillion. This lopsided picture presents the practical consequence and manifestation of the Hotelling argument for a linear economy.

In their seminal book, The Limits to Growth, Meadows, Meadows, Randers, and Behrens (1972) argued rigorously about the limitations to growth and the Hotelling argument. Since then, significant intelectual works have been contributed, and policy consciousness has arisen in developing and practicing the ecological and circular economy paradigm. A more recent and significant formal policy work was done by the European Commission in 2017. Works covering ecological economics, corporate social responsebility, environmental, social and governance (ESG) concerns, ethical and impact investing etc., have indeed strengthened the circular economy paradigm. If the environment is not a concern in the linear economy paradigm, it is certainly the core concern in the ecological and circular economy paradigm. The SDGs essentially have given a serious impetus to this new paradigm with its core being humankind and other species and wealth creation being a means to comprehensive human development and not an end in itself.

In Figure 2a, we sketch an economic paradigm as the result of its emphasis on the human needs. The linear paradigm merely rests on wealth and the circular paradigm rests on needs as a composite reality. At present, Islamic finance is a haläl sub-set of the linear economy paradigm. To be effective in achieving $\mathrm{CHD} / \mathrm{SDGs}$, Islamic finance has to realign its paradegm to-wards circular and ecological economy and away from the current linear paradigm.

Figure (2a) The Maqāṣsid Elements and the Economic Paradigms

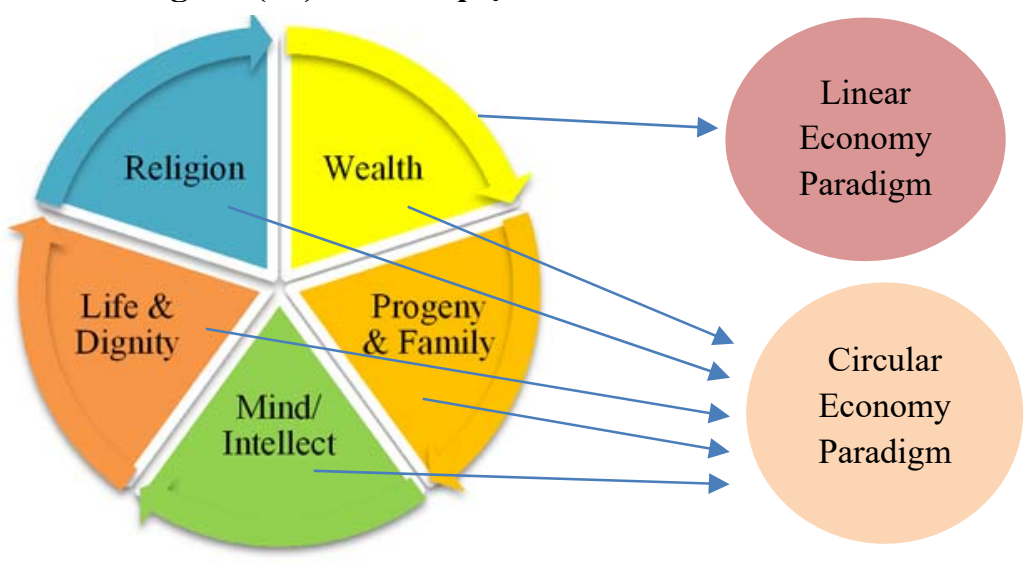


In Figure $2 b$, we summarize four different possibilities of modified paradigms for the Islamic finance and economy for consideration: (A) Islamic economy is partly linear and partly circular; (B) Islamic economy is more linear than circular; (C) Islamic economy is more circular than linear; and (D) an ideal Islamic economy is neither circular nor linear. Islamic finance essentially replaces the interest-based credit system with a deferred sale-based credit system that is to be-come permissible (haläl). The emphasis on the rights of future generations as an objective of the Shari' ah reminds us of the environment. However, in general, Islamic finance has found it sufficient to be halāl within the framework of the linear economy paradigm. In terms of Figure $2 b$, Islamic finance and economy is in \#B state of the paradigm, i.e., more linear than circular. Considering the goal of being effectively instrumental in achieving the SDGs, the desired state of the paradigm is $\# \mathrm{C}$.

A: Islamic Economy is partly linear and
partly circular
This is an approach of indifference between
linearity and circularity of the paradigm and the
characteristic of the current intellectual attitude
within the Islamic finance circles. The approach
is passive and ineffective in terms of contributing
to global policy reforms whether on the CHD or
SDGs agendas.

B: Haläl Economy is more linear than circular Arguably, the Islamic banks, in general, follow this paradigm with the only difference that all income earned must be halāl, although there are unresolved issues about some dominant financial contracts like tawarruq (which commercializes lending) and wa'd-wa'd derivatives being haläl. This state can also be characterized as the financialized Islamic economy.

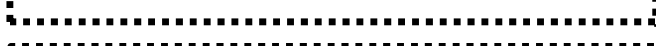

C: Islamic Economy is more circular than linear The Islamic economy paradigm will shift to this level provided the institutions of compassion (qard, zakāh, awqāf and forbearance) are internalized in the financial system and the financial market is linked to the real economy, and consumption and waste are kept in acceptable ranges per Islamic values.

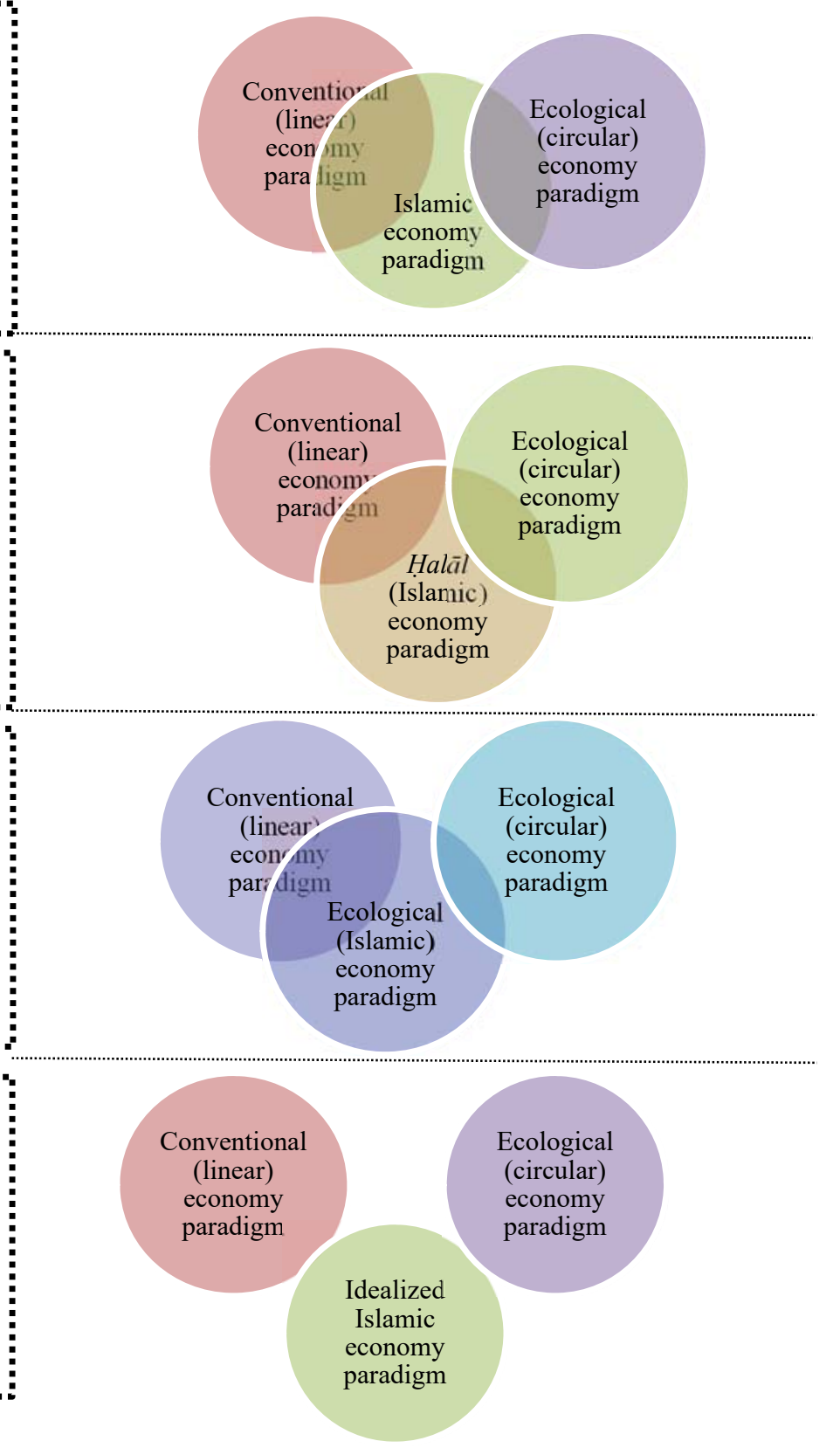

Figure (2b) Islamic Economy Paradigm Choices 


\section{Transform the Architecture}

There is no doubt that for achieving the SDGs, the global financial architecture has to undergo significant transformation. In the absence of a consensus regarding the definition of international financial architecture, we describe it as a set of intertwined institutional parameters. These include: (a) the unalterable foundational principles concerning business and finance; (b) the universal ethical norms of market practices and business conduct in financial services; (c) the international best practice standards pertaining to financial services and (d) the relevant institutions.

Traditionally, the relevant institutions are the Bank of International Settlements (BIS), Basel Committee for Banking Supervision (BCBS), Financial Action Task Force (FATF), Financial Stability Board (FSB), International Accounting Standards Board (IASB), International Organization of Securities Commissions (IOSCO), International Monetary Fund (IMF), and the World Bank (WB). These institutions have the man-date to ensure safeguarding and strengthening those parameters of the architecture with their different instruments of policy support. Historically, these institutions and the standards set by them have completely ignored the relevance of ecological concerns for systemic stability.

The paper by the University of Cambridge's Institute for Sustainability Leadership in association with the UNEP Finance Initiative (CISL \& UNEPFI, 2014) raises important questions concerning this critical gap in the Basel III banking regulations. However, the SDGs, PRIs, GCPs, and initiatives like the research of the GRI and UN Global Compact (2017) which focuses on ESG and SDG disclosures, are radically influencing the behavior of businesses and their reporting systems worldwide. Hence, the UN and GRI principles and their institutional base now play a proactive role in the transformation of the global financial architecture.
The traditional description of financial architectture is also applicable to the global Islamic financial architecture, covering in particular the Islamic Financial Services Board (IFSB), Accounting and Auditing Organization for Islamic Financial Institutions (AAOIFI), the OIC Fiqh Academy (OIC-FA), and the Islamic Development Bank (IDB), in addition to the international institutions listed. These institutions also do not have any proactive agenda for the ESG concerns and SDG implementation except that in 2016 the IDB and UNDP have signed a MoU for enhancing the role of Islamic finance in SDGs implementation.

The global financial architecture and its Islamic sub-set are designed to function within the framework of the linear economy and cater to its needs and requirements. As mentioned above, the linear economy paradigm does not consider the ecological environment as a depletable resource. It is market-driven - earning more by maximum resource extraction, production, usage, and even waste and more extraction. The global financial system is a part as well as facilitator of this paradigm.

However, over the last few decades as a response to the climate change and the damage done to the eco-logical environment, the competing circular economy paradigm has emerged, in which the environment is considered an essential and depletable resource. The new paradigm which essentially replaces the linear paradigm has received significant support over the last decade and especially with the introduction of the UN SDGs, interest in ESG and humanitarian concerns (see figure 3). The new approach has also received support by successful efforts made in commercial use of solar energy, responsible investment, ethical banking, and companies voluntarily adopting GRI standards and integrated reporting. 
Figure (3) Transformation of global economic paradigm and the new financial architecture
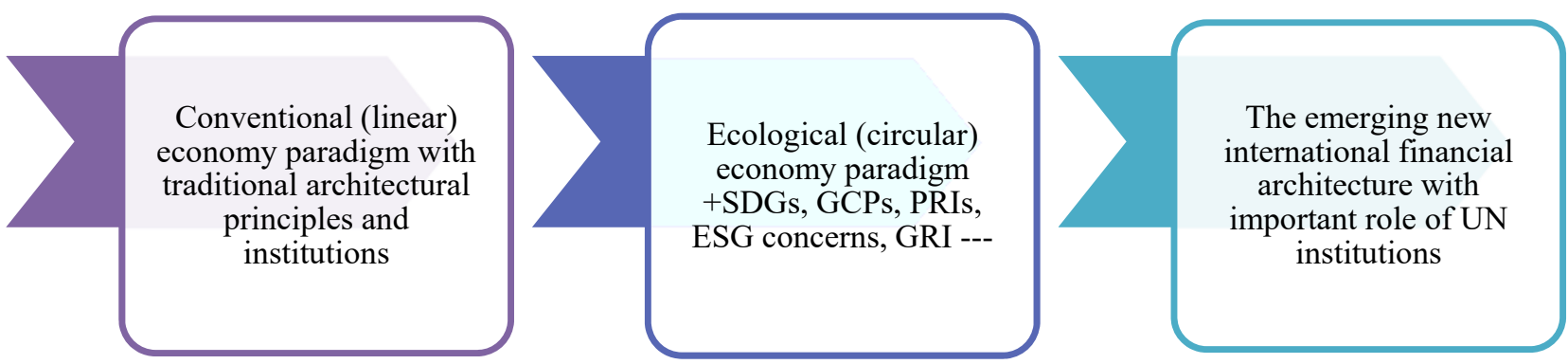

Note: It is important to note that the global financial architecture is traditionally shaped by the BIS led institutional framework. However, the transformation of this architecture is taking place under the influence of initiatives undertaken by the UN affiliated institutions. This institutional transformation offers tremendous opportunity for Islamic finance and economy.

The global financial architecture is a set of universal principles of conducting business, best practice standards, and the institutions concerning the two and their conduct at the global, regional, and national levels. Traditionally, the global financial architecture is affected mostly by the BIS, standard-setting bodies, Financial Stability Forum, IMF and the World Bank. How-ever, as summarized in Figure 4, the SDGs, PRIs, and GCPs have introduced drastic changes in the principles of business conduct and have shifted the center of the global financial architecture to the UN institutions, especially UNDP and private initiatives like the GRI.

The DLT revolution brought by Blockchain and digital currencies has introduced significant financial disintermediation and regulatory uncertainties despite the potential benefits of enhancing access and inclusion, and spreading risk and enhancing resilience.

The emerging new financial architecture descrybed as such in Figure 4, has an international connotetion and, therefore, it needs to be differentiated from its sub-set the "financial infrastructure" which pertains to national elements of the financial architecture. These are infrastructural elements and relate to legal, regulatory, systemic liquidity, financial reporting and transparency, credit reporting, knowledge and educational and advisory services, ratings, payments syste$\mathrm{ms}$, technology and credit reporting, protection of stakeholders, and above all ethical screening and Sharı̄'ah governance. 


\section{Figure (4) Islamic financial architecture in the global context}

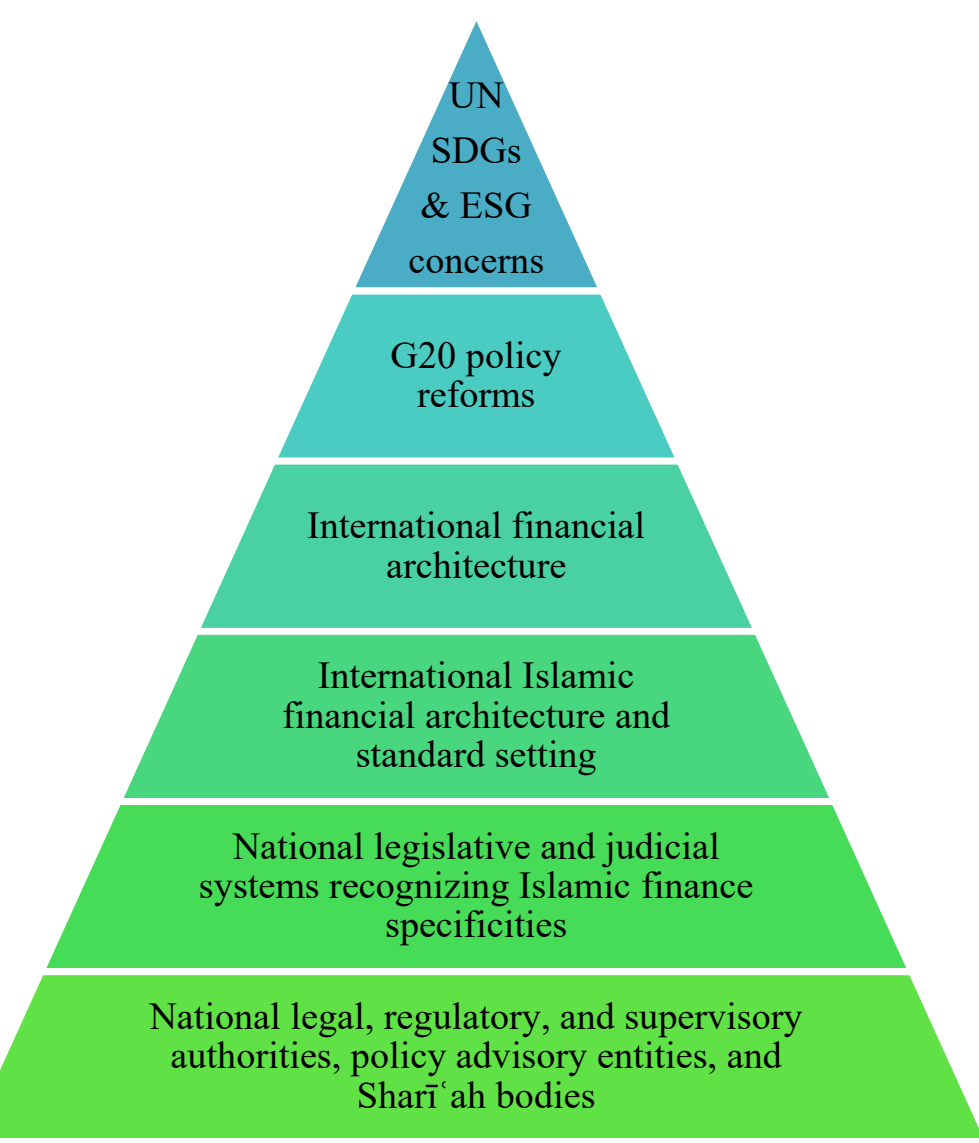

International apex figh academies, and Sharī' ah boards (whose research-driven views/guidance notes are important)

Educational, informational, advisory, structuring, and rating services (cross-cutting services) needed to implement genuine Islamic financial services

Micro-Sharī'ah governance: compliance at the level of institutions, products, services, markets, and users (ongoing financial engineering and product development work)

Derived and adapted best practice standards for Islamic financial services industry (slowly changeable parameters but with significant consensus); SDGs, ESG concerns, PRIs, GCPs, etc.

Received and given principles and architectural foundations of Islamic finance (unchangeable parameters); maqāșid al-Sharì ah 


\section{Synchronize Local Aspirations, National Objectives and Global Goals}

Local aspirations and cultural values, national policies, and global goals are the three foundational pillars of shared prosperity, inclusive and sustainable development, and overall wellbeing. Figure 5 represents this dependent nature of local aspirations, national objectives, and global goals. The more these three pillars are synchronized, the more will be the local ownership of national policies and the more effective the global goals would be.

Figure (5) The three layers of effective policy implementation

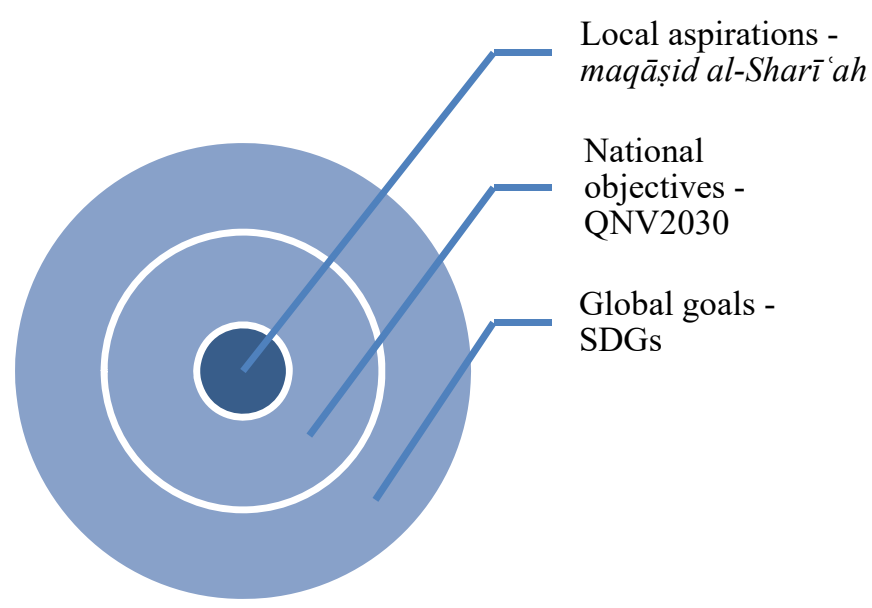

The aversions of local communities to government policies in the IDB member countries are welldocumented in the arguments of opinion leaders. Aversion to interest-based financial services, aversion to educational services, aversion to health services all have been the result of these services being in conflict with local aspirations. In the development and MDGs target studies, these would be known as religious or cultural barriers, and considered as voluntary forms of exclusion (see for example, World Bank, 2014, p.16, figure 1.1). The alternative prescriptions to remove the barriers have been competing. For example, the "Interest is not rib $\vec{a}$ " argument is always being supported by policies and this applies to policy interventions to remove the barriers to educational, health, and other services. The result has been a conflict of policies with local aspiration and thus failure of MDGs in IDB member countries. Figure 6 summarizes this conflict with local aspirations and the millennium development goals (MDGs) regime during 2000-2015.

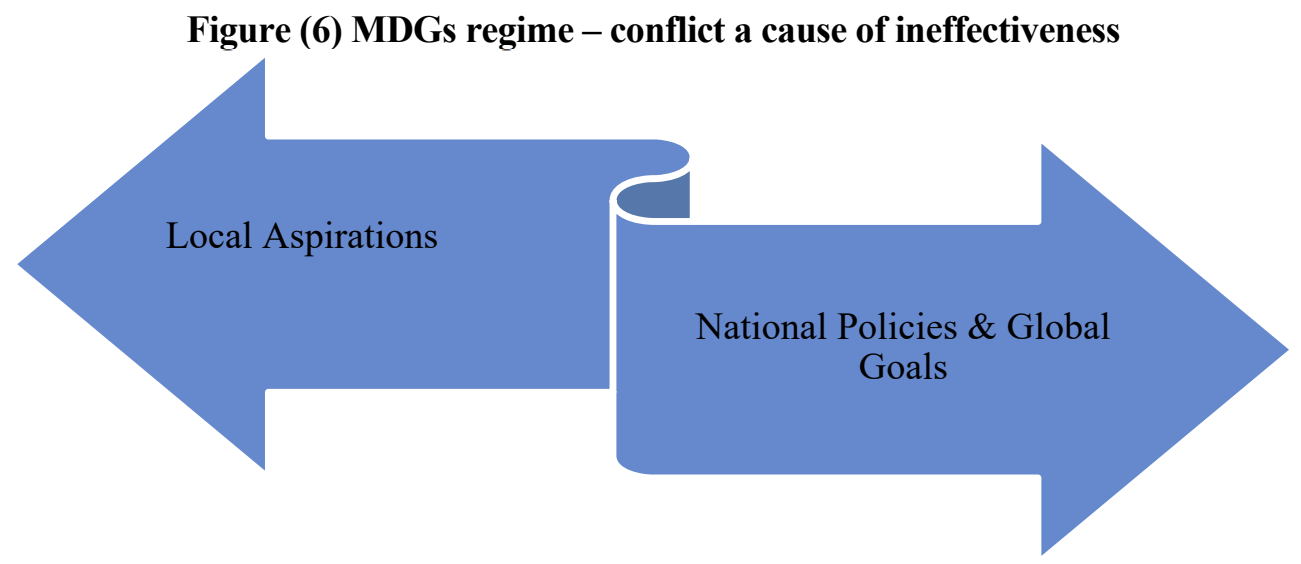


On the other hand, Islamic finance offers a good example of a prescription that caters to local preferences and hence guarantees inclusion. The same could also be relevant for other services like educational, health, and social development programs. Qatar National Vision 2030, with four pillars - people, economy, culture, and environment, is an example of an outstanding policy prescription that caters to such local preferences and hence, synchronizes local aspiration and global goals. A mapping and comparison of the three in Figure 7 shows a complete synchrony bet-ween the pillars with a realigned financial architecture.

\section{Figure (7) SDGs regime - reasons for optimism}

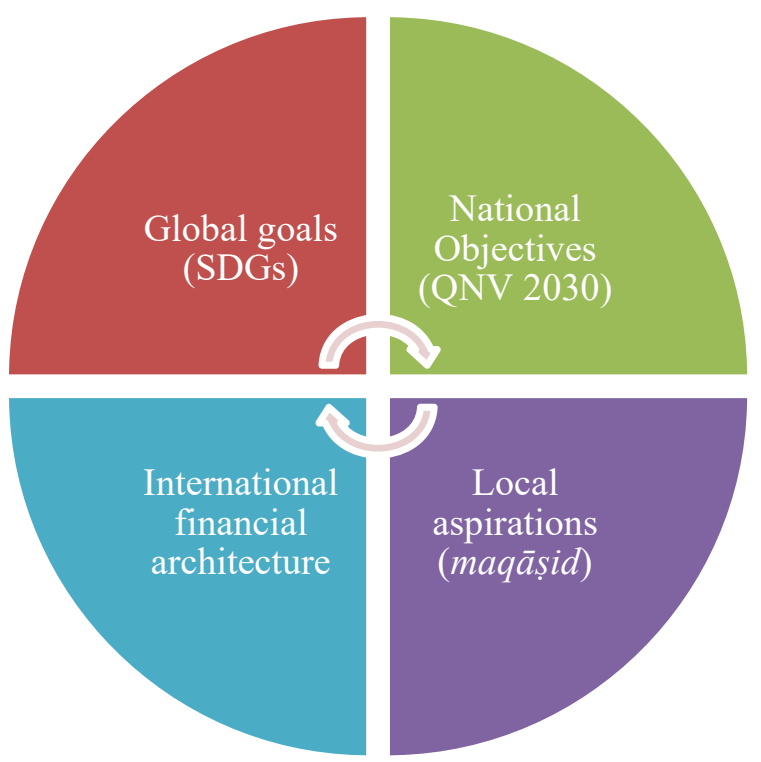

\section{Reform Sharī ah Governance - Haläl is Essential but Insufficient}

Compliance with local aspirations (maqāṣid alShari 'ah) is a very broad and high-level policy requirement in the national context, whether it is in the juristic, educational, health, media, cultural, financial domains, and so on. In the context of Islamic finance, there is an internal process carried out by Islamic financial institutions (IFIs). In at least five jurisdictions, Sharī ah governance (SG) is a regulatory requirement prompted by the eventuality of systemic risk of Sharī ah non-compliance. Recognition of systemic significance of Sharī'ah non-compliance necessitates a two-tier SG system. Tier one of SG is at the level of the regulator, who needs to oversee and have surveillance on the second tier - the service provider. In most other jurisdictions, where there are practices of Islamic financial services (IFS), the systemic significance of Sharīalah non-compliance is not recognized. In such jurisdictions, service providers implement the SG voluntarily as a financial engineering, product development, and behavioral marketing strategy.

In the existing academic works and guiding notes by regulators and standard setters, SG implies the application and assurance of the principles of Shari' ah at these two levels. However, the focus of SG has thus far been at the micro-level, covering the Sharīah permissibility of products and services offered by the IFIs. The purpose of the SG as such is to establish the haläl paradigm in financial services covering business conduct and the earning of permissible income. This is done within the overall framework of the conventional capitalistic linear economy paradigm. 
This micro approach is indeed essential but insufficient. Moreover, on one hand the approach creates structural risks resulting in something being treated as halāl and not halāl simultaneously, which will eventually impede the progress and resilience of Islamic finance. On the other hand, society's overall aspirations and objectives (reflected in the maqāsid al-Shari ${ }^{-} a h$ ) are left outside the scope of SG. Furthermore, the micro-objective approach also ignores the significant transformation that is taking place in the global financial architecture as mentioned above. Therefore, there is a need to redefine the purpose of SG to cover - in addition to establishing the haläl paradigm - the internalization of the institutions of compassion which include qard, zakāh, and awqāf ; forbearance; and ecological and social concerns (World Bank and Islamic Development Bank Group, 2016).

In Figure 8(a) we describe the different layers of Shari' ah governance. In addition to the micro-level, IFS comprise of the intermediate meso-level components including educational, financial reporting, transparency, information, and advisory infrastructures and services. For example, the rising trend of Sharīah, SRI, and ESG screening of investment opportunities is one of the most effective uses of technology to empower investors in the imposing market discipline in favor of local preferences. The macro-level layer of IFS includes the courts, the legal and tax systems, and the regulatory and supervisory infrastructures. These regulatory infrastructures would also include the implementation of international best practice standards and the provision of systemic liquidity, safety-nets, and an overall level playing field. At the global level, we are referring to the setting of international standards and the interaction of Islamic finance principles with international institutions, standards, norms, and legal regimes.

At each level of the micro, intermediate, macro and global layers, the basic parameters of SG need to be identified, discussed, analyzed and modified. This needs to be done with perspectives of the changing global financial architecture where SDGs, ESG, PRIs, GCPs, and humanitarian issues are becoming added concerns. We attempt to identify and discuss the fundamental elements of SG and existing institutional gaps at each layer. Looking ahead, we suggest how best these gaps may be addressed and filled for a locally genuine and globally credible and robust IFS industry.

In light of the above discussion, the strategic goals of Islamic financial services development and implementation are:

(i) Enhancing financial inclusion and access to finance by all businesses and segments of the population;

(ii) Genuineness, stability and resilience of the Islamic financial services;

(iii) Depth (meeting all needs) and breadth (reaching all geographic areas and population and business segments) of the financial services; and

(iv) Promoting alertness and sensitivity to climatic and humanitarian concerns and responsible investment. 
Figure (8a) Sharī ah governance layers

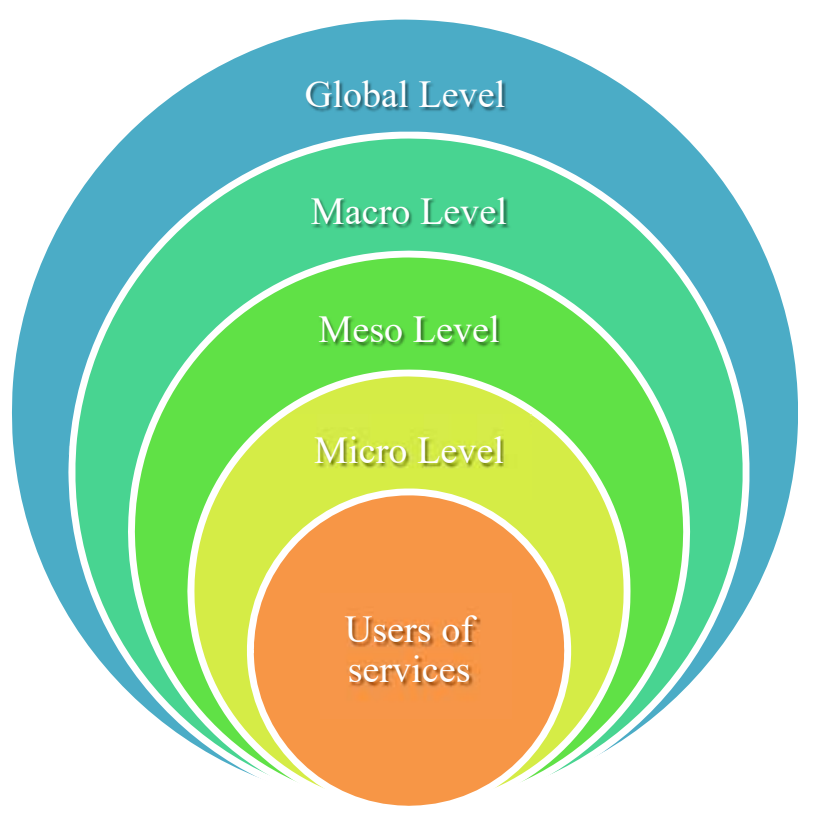

International standard setters

$\square$ Legal, regulatory and tax framework and policies

- Knowledge, educational, capacity building, information, and advisory services and providers

$\square$ Financial services and the institutions and markets providing them

a Uses and users

\section{Figure (8b) Internalizing the institutions of compassion to implement SDGs}

Reformed scope of Sharī'ah governance

Existing scope of Sharī ah governance
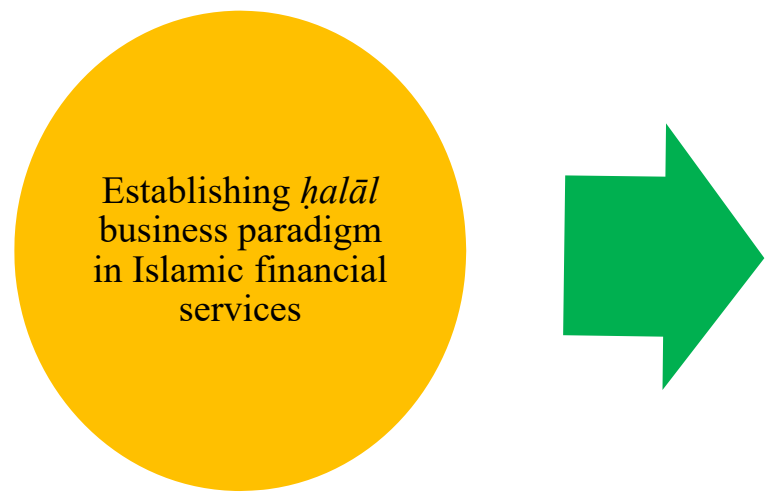

Halāl business paradigm + ethical screening + genuiness of contracts and internalizing the institutions of compassion (zakāh, awqāf, charities, interest-free loans, forebearance, concerns of ecology and future generations, etc.), also encompassing maqāșid, SDGs, PRIs and GCPs in financial contracting and investment decision 


\section{Redesign Financial Products}

Hotelling's basic argument was that the design of interest-based financial contracts will efficiently facilitate the transformation of natural resources into man-made financial capital and ensure wealth creation. The aspiration of society to preserve the ecological system did not make economic/rational sense to him. The same conflict of societal aspirations vis-à-vis wealth creation still prevails even within the framework of Sharīa ah governance, which is the central theme of Islamic finance. The design of financial contracts instead of being instruments of risk transference could better reflect societal aspirations by risk-sharing. The existing Sharīah governance institutions, which are core institutions of the Islamic financial architecture, do not address this concern at all. In most of these existing works, SG implies the application and assurance of the principles of Shari' ah at the micro-level covering the governance and conduct of providers of the Islamic financial services (IFS) with the core and targeted objective of making the services halāl. The relevant guidance notes issued by the IFSB and the AAOIFI are also anchored by the micro-approach. Regulators, whether they have Sharīah boards housed inside national regulatory authorities (e.g., Malaysia, Indonesia, Pakistan, etc.) or whether they do not have such national institutional set-ups (e.g., Saudi Arabia, Bahrain, Qatar, etc.) all share the same micro-outlook towards SG. The consequences are structural risks, financialization, and ecological indifference.

\subsection{Structural Risk in the Design of Financial Products}

It may be argued that this overall micro and more individuated approach to SG provides enough space and incentive for financial engineering and product development. However, in fact, such a micro approach that considers being haläl as essential and sufficient conditions for Islamic financial architecture replicates interest-based contracts where the Hotelling argument prevails. Moreover, this approach also gives rise to structural risks in the design of financial products impeding the achievement of the strategic goals set for the IFS and the SDGs.

Figure (9) Structural risk in the design of șukūk

(a)

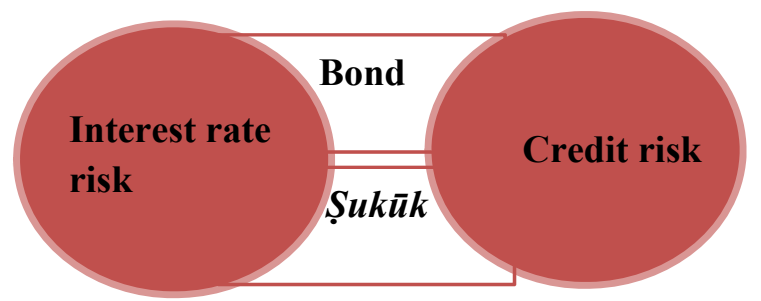

(b)

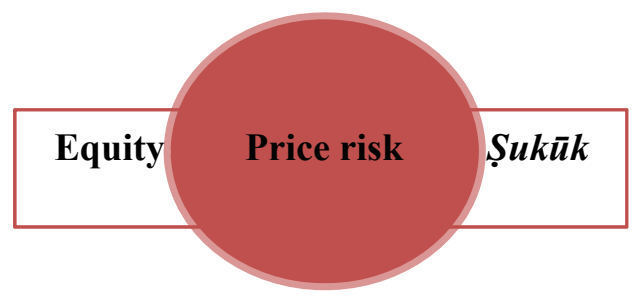

(c)

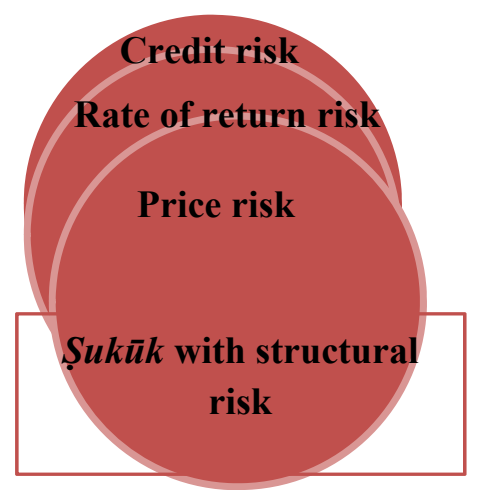


Structural risk in the design of a financial contract is the fragility of the contract due to opposing views concerning the contract's Sharīah validity. In figure 9 (a) șukuk replaces a bond having identifiable credit risk and rate of return risk. This position concerning suku $k$ is the consensus view of stakeholders - issuers, underwriters, legal advisors, investors, and above all the Sharī'ah advisors who allow repurchase of $s u k \bar{u} k$ assets at initial price. However, figure 9 (b) shows the position of Sharīah scholars who allow repurchase but only at market price prevailing at the future time of repurchase. The contradictory positions underlying figure 9 (a) and (b) give rise to figure 9 (c) which means that since (a) and (b) exist, it is not possible to separate the three risks; price risk as in (b), and interest rate risk and credit risk as in (a) are bundled and inseparable in (c). This state of affairs concerning the design of financial products makes the architectural foundations of Islamic finance shaky.

Structural risk may be confused with what is referred to as Shari' ah risk where the two need to be distinguished. If there were a consensus on the Shari' ${ }^{\top} a h$ validity of these contracts that are dominating Islamic finance, there would not have been any structural risk in the design of these cont-racts. In that case, there could still have been Shari'ah risk showing the potential distance of a specific contract from what is considered as a Sharī'ah compliant structure. However, the reality in the present case is that the contracts are Sharī ah comp-liant to one group of scholars and non-compliant to another group, complaint to one apex Sharīah body and non-compliant to another one. Such disputes on fundamental issues not only follows the linear economy paradigm but also shakes the architectural foundations of Islamic finance.

\subsection{Financialization}

In terms of the design of financial contracts, the typical consequence of Hotelling theory for the global economy was summarized in figure 2. Global financial assets and derivatives far exceed global GDP. In theory, Islamic finance controls financializetion as finance cannot be created without real goods and services. However, this theoretical premise of Islamic finance does not hold in practice. Important examples are bay'al-inah (selling on cash and buying-back on credit) and bay' al-tawarruq (buying on credit and selling-back on cash); the first contract is now dominant in the global sukük market and the second is dominant in the financing offered by the Islamic banks. Both are designed to bypass the theoretical premise and are effectively applied with the approval of Shari'ah scholars within the microSharī'ah governance framework. One group of scholars working for banks and service providers argue that selling on cash and buying-back on credit or buying on credit and selling-back on cash whichever best represents the client's economic circumstances is a legitimate out-come of a trading transaction and the client's need for cash is fulfilled in a Sharî 'ah compliant (halāl) manner. However, another group of Shari'ah scholars mostly independent in their standing argue that both these contracts are fictitious trading and are, in fact, a legal arbitrage to circumvent the prohibition of rib $\bar{a}$ and therefore are Sharī'ah non-compliant. So much so that even the two apex Shar' 'ah bodies of the IFS, namely, the OIC Figh Academy and the AAOIFI Sharīah Boards have opposing guidance notes pertaining to the two contracts; the first banning and the second allowing. The result of the halāl is sufficient approach has the added disadvantage of leading to excessive leverage, and potentially a market for "Islamic" derivatives, having the same consequence as depicted in fig 2; financial assets and derivatives exceeding real GDP 10-fold.

The stability and resilience of the financial architecture will depend on the robustness of the foundational principles. The structural risk identified as such is related to the architectural foundations of Islamic finance and, therefore, is more severe in nature than recognized. Since there is no agreed upon Sharīah compliant structure, the Sharī'ah risk becomes irrelevant. Hence, within the IFSB universe of identified risks, this rather most virulent risk remains unidentified posing a real threat to the genuineness, stability, and resilience of the Islamic financial architecture.

\subsection{Sustainability Gaps}

The existing Islamic financial contracts including sukūk are, in their design, either indifferent or even implicitly counter sustainability. A sustainable design of a financial contract will explicitly be pro towards ecological and social concerns. Many sovereign 
șukukk are designed to serve social purposes by developing the physical infrastructure. An example is the Hamad Medical City in Doha, which was financed by a sukūk issuance. The structure of similar șukūk can be designed to be sustainable by documenting, for example, the waste management systems, use of green energy, and the social aspects of the project being financed. There is an obvious gap in the design of Islamic financial contracts and products in this regard which can be conveniently filled with proper policy inducement and regulatory support.

\section{Incentivize Waste Control and Management}

Waste control and management (WCM) is of primary importance to ensure safeguarding environmental, promoting recycling, and the ecological economic paradigm. WCM strategies and targets have been given an important status and priority in the European Union and in other parts of the world. In these countries separate collection of waste remains one of the challenges. Increasingly, companies are integrating disclosures about their WCM policies in reporting. However, in the IDB member countries, except for a few exceptions, WCM is an unfamiliar idea. Government policies at various tiers as well as regulatory guidelines can contribute substantially in introducing WCM initiatives at different levels including house-holds and businesses.

Significant emphasis has been attached to the role of SMEs in promoting inclusive economic development and promoting shared prosperity. Regulatory guidelines and support to SMEs within the ecological economic paradigm could be more consistent with the SDGs and ESG concerns. Infrastructure financing is another pertinent area where Islamic finance is expected to contribute and where waste reduction and management has to attract attention on priority basis. For a comprehensive coverage of the potential policy guide-lines, legislative proposals, and potential initiatives on waste, see European Commission (2017) on the action plan for the implementation of the circular economy.

\section{Encourage Integrated Disclosures}

In the impact investment field, the socially responseble investors - SRI and ESG oriented companies have already started offering voluntary disclosures on
SDG and ESG strategies, activities, and achievements. Khan and Mohomed (2017) show that some Islamic banks like the Bangladesh Islamic Bank Limited are offering more voluntary information on ESG related concerns. GRI and UN Global Compact (2017) offers a comprehensive template for such disclosures. The template is 223 pages in size covering all the 17 SDGs and 169 targets. Since it is not possible to present a meaningful abstract of such a large document, here we present two quotes from the Chief Executive of GRI and from the CEO of the UN Global Compact who have jointly published the report. In the words of the Chief Executive of GRI:

At a time when the revenues of large companies exceed the GDP of many countries and supply chains stretch around the world, the private sector plays a vital role in achieving the Sustainable Development Goals (SDGs). This analysis of the goals and targets is a first step towards a unified mechanism to help companies report on the SDGs in a comparable and effective way. By reporting on their progress, companies will improve their performance which will enable meaningful progress towards achieving the SDGs. (p. 9)

The CEO of UN Global Compact said:

The SDGs provide a unique opportunity to elevate communication on sustainability. Governments have emphasized this agenda through SDG 12 recognizing how important it is for companies to adopt sustainable practices and integrate this information into their reporting cycles. The expectations on companies are huge. Companies that align repor-ting and communication with the SDGs will be speaking in the same language that increasingly is adopted by governments, foundations, NGOs and even investors. (p. 9)

Some companies have already initiated disclosure concerning their contributions to SDGs implementation. Regulatory authorities can play a tremendously important role in expecting from the companies to start using the template and gradually adapting it within a reasonable period.

\section{Conclusions and Implications}

Our foregoing discussion shows that the linear economy paradigm is transforming into the circular economy paradigm, especially driven by SDGs and through active policy support and strategic targets 
within the European Commission. The global financial architecture is transforming because of the responses of businesses to the various UN initiatives. The ways that companies had been doing businesses is also changing and reporting is becoming more comprehensive covering SDGs and ESG concerns. However, the global best practice standards - Basel III, IFSB standards, financial reporting standards etc. - still cater to the linear economy paradigm. The CISL and UNEP-FI (2014) study formally raises this important gap in the standards and is calling upon the standard setters and regulators to revise the existing standards in the light of the new but rapidly changing realities. This call is equally relevant for the IFSB and AAOIFI standards. Some of these are listed here:

(a) IFSB to recognize in its approach and standards the ESG concerns and SDGs, PRIs, GCPs, etc., and to identify tasks and responsebilities under Pillar 2 and disclosures requirements under Pillar 3. Under Pillar 1 the IFSB can encourage green șukūk by different incentives.

\section{References}

Bank for International Settlements. (2018). Statistical release: OTC derivatives statistics at end-June 2018. Retrieved from: https://www.bis.org/publ/otc_hy1810.pdf

Bello, A., \& Suleman, A. (2011). The Challenge of Achieving the Millennium Development Goals in IDB Member Countries in the Post-Crisis World (IDB Occasional Paper No. 16). Retrieved from: http://www.iefpedia.com/english/wpcontent/uploads/2011/12/Abdullateef-Bello.pdf

Cambridge Institute for Sustainability Leadership [CISL], \& United Nations Environment Programme Finance Initiative [UNEP-FI]. (2014). Stability and Sustainability in Banking Reform: Are Environmental Risks Missing in Basel III? Cambrdige, UK \& Geneva, Switzerland: Author. Retrieved from: http://www.unepfi.org/fileadmin/documents/StabilityS ustainability.pdf

Chapra, M. Umer. (2008). The Islamic Vision of Development in the Light of Maqasid al-Shariah. Jeddah, KSA: Islamic Research and Training Institute, Islamic Development Bank.

Costanza, R., Cumberland, J.H., Daly, H., Goodland, R., Norgaard, R.B., Kubiszewski, I., \& Franco, C. (b) AAOIFI to consider GRI and UN Global Compact (2017) and encourage replication by its members wherever applicable.

(c) Central banks to encourage green assets and design of contracts based on long-term risk sharing.

(d) Security regulators to enhance the ethical screening methodologies in line with SDGs, PRIs, GCPs, and GRI.

(e) Finance Ministries to enhance coordination with regulators and other stakeholders on the SDG implementation.

This paper has only described the broader outline for a paradigmatic and regulatory reform of Islamic finance. The transformative global scene provides an excellent opportunity for researchers to undertake more work with an objective to contribute to transforming economies to become more responsible, inclusive, and resilient and to ensure shared prosperity and wellbeing.

(1997). An introduction to ecological economics. Florida, USA: CRC Press.

European Commission [EC]. (2017). Report from the Commission to the European Parliament, the Council, the European Economic and Social Committee and the Committee of the Region on the Implementation of the Circular Economy Action Plan. Brussels, Belgium: Author. Retrieved from:

http://ec.europa.eu/environment/circulareconomy/implementation_report.pdf

Global Reporting Initiative [GRI], \& United Nations Global Compact. (2017). Business Reporting on the SDGs: An Analysis of the Goals and Targets. Amsterdam, Netherlands: Author. Retrieved from: https://www.globalreporting.org/resourcelibrary/GRI_ UNGC_Business-Reporting-on-SDGs_Analysis-ofGoals-and-Targets.pdf

Hotelling, H. (1931). The Economics of Exhaustible Resources. Journal of Political Economy, 39(2), 137175.

Khan, Tariqullah, \& Mohomed, Amiirah. (2017). Ethical Banking and Islamic Banking: A Comparison of Triodos Bank and Islami Bank Bangladesh Limited. Islamic Economic Studies, 25(Special Issue), 111-154. 
McKinsey \& Company, McKinsey Global Institute. (2017). The New Dynamics of Financial Globalization: August 2017. Retrieved from:

https://www.mckinsey.com/ /media/McKinsey/Industr ies/Financial\%20Services/Our\%20Insights/The\%20ne w\%20dynamics\%20of\%20financial\%20globalization/ MGI-Financial-globalization-Executive-summaryAug-2017.ashx

Meadows, D.H., Meadows, D.L., Randers, J., \& Behrens, W. W. III. (1972). The Limits to Growth: A Report for the Club of Rome's Project on the Predicament of Mankind. New York, USA: Universe Books.

Tag el-Din, Seif Ibrahim. (2013). Maqasid Foundations of Market Economics. Edinburgh, UK: Edinburgh University Press.

United Nations Development Programme [UNDP], Istanbul International Center for Private Sector in Development [IICPSD], \& Islamic Research \& Training Institute, Islamic Development Bank Group [IRTI, IDB]. (2017). I for Impact: Blending Islamic Finance and Impact Investing for the Global
Goals. Istanbul, Turkey, \& Jeddah, KSA: Authors. Retrieved from:

http://www.irti.org/English/News/Documents/IRTI_U N_Islamic_Financial_Report.pdf

World Bank. (2014). Global Financial Development Report 2014: Financial Inclusion. Washington, USA: Author. Retrieved from:

http://siteresources.worldbank.org/EXTGLOBALFINR EPORT/Resources/88160961361888425203/9062080-1364927957721/GFDR-

2014_Complete_Report.pdf

World Bank, \& Islamic Development Bank Group. (2016). Global Report on Islamic Finance: Islamic Finance - A Catalyst for Shared Prosperity. Washington, USA: Author. Retrieved from: https://openknowledge.worldbank.org/bitstream/handle /10986/25738/9781464809262.pdf? sequence $=5$

World Bank. (2018). World Development Indicators: Data Bank. Retrieved from: https://databank.worldbank.org/data/reports.aspx?sourc $\mathrm{e}=2 \&$ type $=$ metadata\&series $=$ NY.GDP.MKTP.CD\#

Tariqullah Khan is currently Professor of Islamic Finance at the College of Islamic Studies, Hamad Bin Khalifa University, Qatar Foundation, Doha. He was previously with the Islamic Development Bank Group as Co-Lead of Global Islamic Financial Industry Development Initiative and Division Chief, Islamic Banking and Finance, Islamic Research and Training Institute (IRTI). He was also a visiting scholar at the Harvard University Law School during summer 2011, as well as at the Stanford University Law School during the summer of 2017.

E-mail: tkhan@hbku.edu.qa 


\section{Appendix}

\section{Sustainable Development Goals, Global Compact Principles, and Principles of Responsible Investment}

This appendix shows the principles that are transforming the global financial architecture. The UN Sustainable Development Goals (SDGs) are given in section A. Section B presents the UN Global Compact Principles. The Principles of Responsible Investment, which are supported by the $\mathrm{UN}$, are given in section $\mathrm{C}$.

\section{A. UN Sustainable Development Goals}

SDG Goal 1: No poverty.

SDG Goal 2: Zero hunger.

SDG Goal 3: Good health and wellbeing.

SDG Goal 4: Quality education.

SDG Goal 5: Gender equality.

SDG Goal 6: Clean water and sanitation.

SDG Goal 7: Affordable and clean energy.

SDG Goal 8: Decent work and economic growth.

SDG Goal 9: Industry, innovation, and infrastructure.

SDG Goal 10: Reduced inequalities.

SDG Goal 11: Sustainable cities and communities.

SDG Goal 12: Responsible consumption and production.

SDG Goal 13: Climate action.

SDG Goal 14: Life below water.

SDG Goal 15: Life on land.

SDG Goal 16: Peace, justice, and strong institutions.

SGG Goal 17: Partnership for the goals.

\section{B. UN Global Compact Principles}

Human rights:

Principle 1: Businesses should support and respect the protection of internationally proclaimed human rights; and

Principle 2: Make sure that they are not complicit in human rights abuses.
Labor:

Principle 3: Businesses should uphold the freedom of association and the effective recognition of the right to collective bargaining;

Principle 4: The elimination of all forms of forced and compulsory labor;

Principle 5: The effective abolition of child labor; and

Principle 6: The elimination of discrimination in respect of employment and occupation.

Environment:

Principle 7: Businesses should support a precautionary approach to environmental challenges;

Principle 8: Undertake initiatives to promote greater environmental responsibility; and

Principle 9: Encourage the development and diffusion of environmentally friendly technologies.

Anti-corruption:

Principle 10: Businesses should work against corruption in all its forms, including extortion and bribery.

\section{UN-Supported Principles of Responsible Investment}

Principle 1: We will incorporate ESG issues into investment analysis and decision-making processes.

Principle 2: We will be active owners and incorporate ESG issues into our ownership policies and practices.

Principle 3: We will seek appropriate disclosure on ESG issues by the entities in which we invest.

Principle 4: We will promote acceptance and implementation of the Principles within the investment industry.

Principle 5: We will work together to enhance our effectiveness in implementing the Principles.

Principle 6: We will each report on our activities and progress towards implementing the Principles. 


\title{
إصلاح التمويل الإسـلامي لتحقيق أهداف التنمية المستدامة
}

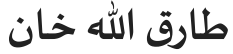 \\ أستاذ التمويل الإسلامي، كلية الدراسات الإسلامية، جامعاة حمل بن خليفة، قطر
}

المستخلص. يسترشد نموذج الاقتصاد والتمويل الإسلامي بدوافع التنمية البشرية الشاملة (CHD)

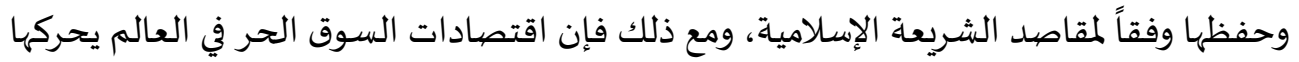

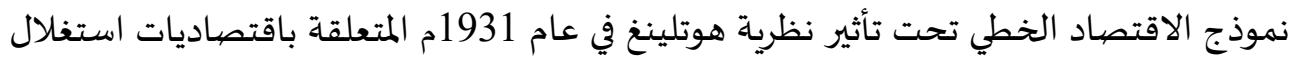
الموارد الطبيعية، حيث لا يتم الاعتراف بالبيئة الإيكولوجية كمورد، إذ تم تصميم الهيكلة المالية العالمية لحماية وحفظ النموذج الاقتصادي الخطي. ومن الناحية العملية ظل التمويل الإسلامي

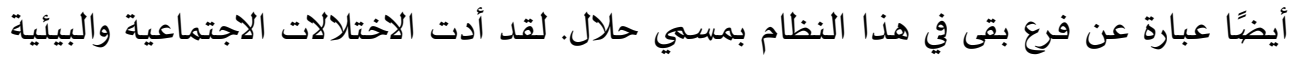

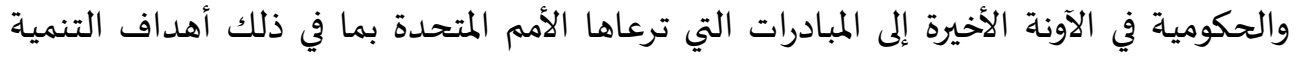
المستدامة (SDGs) التي تسعى إلى تحقيق التنمية البشرية والمحافظة عليها وفقًا لمقاصديد الشريعة التحادية

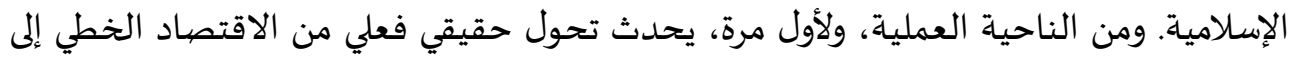

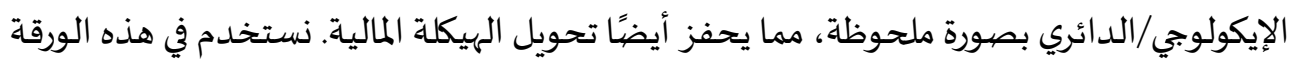

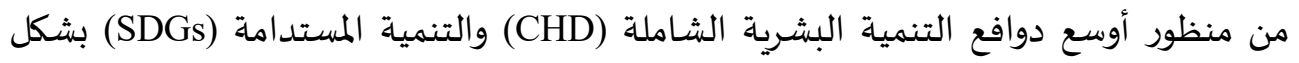

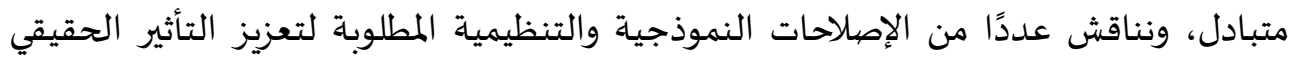

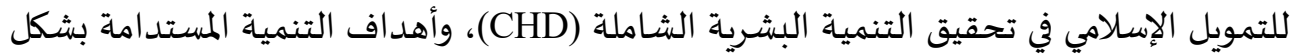
عام. كما تناقش الورقة بصورة أوسع مبادرات الإصلاح المحتملة.

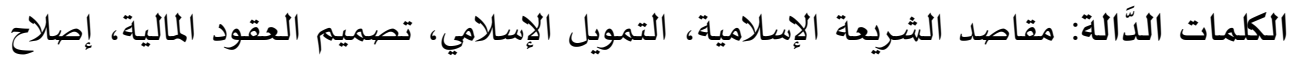

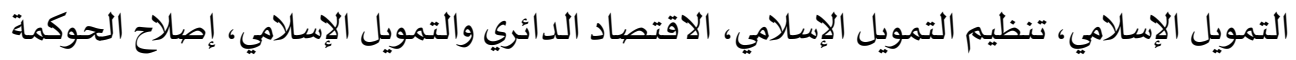
الشرعية، التقرير عن التنمية المستدامة، والتنمية الشاملة والتمويل الإسلامي.

Qصنيف Q01, Q56: JEL

تصنيف B5, H51 : KAUJIE 